\title{
ANALISIS KINERJA DINAS TENAGA KERJA DAN TRANSMIGRASI KABUPATEN LAMPUNG SELATAN DALAM MENCEGAH DAN MENYELESAIKAN PERSELISIHAN HUBUNGAN INDUSTRIAL DI KABUPATEN LAMPUNG SELATAN
}

\author{
Drs. Achmad Moelyono, M.H ${ }^{1}$, Selly Asih ${ }^{2}$ \\ achmadmoelyono.utb@gmail.com \\ ${ }^{[1][2]}$ Program Studi Administrasi Publik, Fakultas Ilmu Sosial dan Ilmu Politik, UTB Lampung
}

\begin{abstract}
ABSTRAK
Kinerja Dinas Tenaga Kerja dan Transmigrasi Kabupaten Lampung Selatan dalam mencegah dan menyelesaikan perselisihan hubungan industrial adalah dengan melakukan analisis dengan menggunakan indikator kinerja yaitu, Efektifitas, efisiensi, kualitas, produktivitas, Kualitas kehidupan kerja, dan Inovasi. Dengan melakukan analisis Indikator Kinerja terhadap Kinerja Dinas Tenaga kerja dan Transmigrasi Kabupaten Lampung Selatan dalam Mencegah dan menyelesaikan perselisishan hubungan industrial tersebut. Pihak Dinas Tenaga Kerja dan Transmigrasi bagian Hubungan Industrial Seksi Penyelesaian Hubungan Industrial dapat menyusun rencana kerja dan program yang lebih baik dan terus meningkatkan pelayanan kepada masyarakat. Pencegahan dan penyelesaian hubungan industrial oleh Dinas Tenaga kerja dan transmigrasi Kab. Lampung Selatan ini memiliki dampak terhadap stabilitas kerja baik pihak perusahaan dan pihak pekerja. Yang dapat dilihat selama tiga tahun terakhir 2017-2019 berhasil menyelesaian berbagai macam kasus perselisihan di lingkungan Kabupaten Lampung Selatan. Dapat disimpulkan bahwa kinerja Pencegahan dan penyelesaian hubungan industrial Dinas Tenaga Kerja dan Transmigrasi telah membantu menyelesaian konflik para pekerja dengan perusahaan, sehingga membantu mewujudkan lingkungan kerja yang kondusif dan meningkatkan kesejahteraan masyarakat. Dan menurunkan tingkat pengangguran.
\end{abstract}

Kata Kunci: Kinerja, Transmigrasi, Hubungan Industrial

\section{PENDAHULUAN}

Perselisihan hubungan industrial disebabkan karena pemutusan hubungan kerja merupakan perselisihan yang sering terjadi. Hal tersebut, disebabkan karena hubungan antara pekerja/buruh dengan pengusaha merupakan hubungan yang didasari oleh kesepakatan para pihak untuk mengikatkan diri dalam suatu hubungan kerja. Dalam hal, jika salah satu pihak tidak menghendaki lagi untuk terikat dalam hubungan kerja tersebut, maka sulit bagi para pihak lain untuk tetap mempertahankan hubungan yang harmonis walaupun telah diatur sedemikian rupa hubungan antara pekerja/buruh dengan pengusaha, tetapi tetap saja terjadi Perselisihan Hubungan Industrial.

Perselisihan hubungan industrial antara pekerja dan pengusaha perlu ditekan semaksimal mungkin karena dampak dari perselisihan tersebut sangat merugikan banyak pihak. Kalau pengusaha benar dalam mengambil keputusan dan kebijaksanaan perusahaan sesuai dengan undang-undang dan ada rasa saling membutuhkan maka tidak akan ada perselisihan yang berlarut-larut. 
Tetapi kenyataannya memang masih ada anggapan bahwa kedudukan antara pengusaha dan pekerja tidak sejajar. Pengusaha adalah yang mempunyai uang dan pekerja butuh uang untuk hidup. Hal ini menyebabkan pengusaha mengeksploitasi pekerja untuk mencari keuntungan yang besar dan kurang memberikan hak yang seharusnya diterima oleh pekerja.

Perselisihan hubungan industrial antara pekerja dengan pengusaha dapat diselesaikan dengan prosedur penyelesaian seperti yang diatur dalam Undang-undang Nomor 2 Tahun 2004 tentang Penyelesaian Perselisihan Hubungan Industrial. Langkah pertama yang sebaiknya ditempuh adalah dengan jalan perundingan untuk mencapai musyawarah mufakat antara pekerja dengan pengusaha. Namun biasanya langkah tersebut jarang tercapai. Oleh karena itu, masalah perselisihan biasanya diserahkan pada instansi yang berwenang di bidang ketenagakerjaan, yaitu Dinas Tenaga Kerja untuk menyelesaikan setiap perselisihan hubungan industrial yang terjadi antara pekerja dengan pengusaha.

Dinas Tenaga Kerja dan Transmigrasi Kabupaten Lampung Selatan yang salah satu tugasnya adalah menyelesaikan perselisihan hubungan industrial pada tingkat mediasi.Perselisihan Hubungan Industrial sesuai dengan Pasal 1 ayat (1) Undang undang No.2 Tahun 2004 Tentang perselisihan Hubungan Industrial menjelaskan bahwasannya Perselisihan Hubungan Industrial adalah perbedaan pendapat yang mengakibatkan pertentangan antara pengusaha atau gabungan pengusaha dengan pekerja/buruh atau dengan serikat pekerja/buruh karna adanya perselisihan

Dalam pelaksanaan pembangunan nasional melalui pemerintah daerah, tenaga kerja mempunyai peranan yang sangat penting dan strategis sebagai pelaku dan tujuan pembangunan. karena itu sesuai dengan peran dan kedudukannya diperlukan pembangunan ketenagakerjaan untuk meningkatkan kualitas bekerja dan peran sertanya dalam pembangunan serta meningkatkan perlindungan tenaga kerja beserta keluarganya sesuai dengan harkat dan martabat manusia.

Hubungan Industrial adalah suatu sistem yang terbentuk antara para pelaku usaha dalam proses produksi barang dan jasa yang terdiri dari unsur pengusaha, pekerja/buruh dan pemerintah yang didasarkan pada nilai -nilai Pancasila dan UUD 1945. Perselisihan pemutusan hubungan kerja dan perselisihan antar serikat pekerja/serikat buruh hanya dalam satu perusahaan.

\section{METODE}

Penelitian menggunakan pendekatan yuridis normatif karena dalam penelitian ini melihat masalah hukum sebagai kaidah yang dianggap sesuai dengan penelitian yuridis normatif.

Metode yang digunakan dalam penelitian ini deskriptif kualitatif. Yaitu penelitian yang bertujuan untuk memberikan penjelasan mengenai 
fenomena yang terjadi pada masa sekarang, serta untuk menggambarkan secara sistematis, factual dan akurat mengenai fakta-fakta atau sifat- sifat dan hubungan antara fenomena yang diteliti. (Moleong, 2007:21)

Dalam metode penelitian kualitatif hasil analisis tidak tergantung dengan jumlah, tetapi data yang dianalisis dari berbagai pandangan. Penelitian yang dilakukan meliputi kegiatan pengumpulan data, penyususnan data dan analisis data. Pada penelitian kualitatif, teori tidak secara mutlak dibutuhkan sebagai acuan penelitian. Teori sebagai hasil proses induksi dan deduksi dari pengamatan fakta. Teori pada dasarnya merupakan hasil akhir dari penelitian kualitatif yang disusun melalui proses pengumpulan data, menguji keabsahan data, interpretasi data dan menyusun teori. (Purhantara, 2010:58)

\section{ANALISIS DAN PEMBAHASAN}

\subsection{Penyelesaian Perselisihan Hubungan Industrial}

Perselisihan hubungan industrial adalah perbedaan pendapat yang mengakibatkan pertentangan antara Pengusaha atau gabungan Pengusaha dengan Pekerja/Buruh atau Serikat Pekerja/Serikat Buruh karena adanya perselisihan mengenai hak, perselisihan kepentingan, perselisihan pemutusan hubungan kerja dan perselisihan antar serikat pekerja/serikat Buruh dalam satu perusahaan (Pasal 1 angka $1 \mathrm{UU}$ No. 2 Tahun 2004 tentang Penyelesaian Hubungan Industrial).
Perselisihan hubungan industrial mayoritas terjadi dikarenakan berbagai faktor. Berdasar data yang didapat, mayoritas perselisihan diakibatkan karena empat faktor yang terdiri atas: (1) Jumlah pekerja lebih dari jumlah kesempatan untuk bekerja; (2) Perkembangan modernisasi di pabrik sehingga tidak membutuhkan pekerja yang banyak dikarenakan adanya teknologi; (3) Mesin, komputer lebih pintar dari manusia; dan (4) Peraturan ini kadang-kadang kurang mampu bersaing dengan waktu. Keempat hal tersebut merupakan faktor yang mayoritas sering menyebabkan adanya perselisihan atau sengketa diantara pekerja, di mana terkait dengan hal tersebut sering terjadi diakibatkan karena proses managerial.

\subsubsection{Perundingan Bipatrit}

Perselisihan hubungan industrial diharapkan dapat diselesaikan melalui perundingan bipartit, dalam hal perundingan bipartit gagal, maka penyelesaian dilakukan melalui mekanisme mediasi atau konsiliasi. Bila mediasi dan konsiliasi gagal, maka perselisihan hubungan industrial dapat dimintakan untuk diselesaikan di Pengadilan Hubungan Industrial.

Berdasarkan pasal 3 ayat 1 UU No. 2 Tahun 2004, perundingan bipartit adalah perundingan antara pengusaha atau gabungan pengusaha dan pekerja atau serikat pekerja/ serikat buruh atau antara serikat pekerja /serikat buruh dan serikat pekerja/ serikat buruh yang lain dalam satu perusahaan yang berselisih. Perundingan Bipartit adalah 
perundingan secara musyawarah untuk mencapai mufakat.

Penyelesaian melalui perundingan bipartit harus diselesaikan paling lama 30 hari kerja sejak perundingan dilaksanakan. Apabila perundingan bipartit mencapai kesepakatan maka para pihak wajib membuat Perjanjian Bersama dan didaftarkan di kepaniteraan Pengadilan Hubungan Industrial.

\subsubsection{Konsiliasi}

Penyelesaian konsiliasi dilakukan melalui seorang atau beberapa orang atau badan yang disebut sebagai konsiliator yang wilayah kerjanya meliputi tempat pekerja/buruh bekerja, dimana konsiliator tersebut akan menengahi pihak yang berselisih untuk menyelesaikan perselisihannya secara damai.

\subsubsection{Mediasi}

Mediasi hubungan industrial adalah penyelesaian perselisihan hak, perselisihan kepentingan, perselisihan pemutusan hubungan kerja dan perselisihan antar serikat pekerja/serikat buruhhanya dalam satu perusahaan melalui musyawarah yang ditengahi oleh seorang atau lebih mediator yang netral (Pasal 1 angka 1 UU No. 2 Tahun 2004).

Proses mediasi dibantu oleh seorang mediator hubungan industrial, yang merupakan pegawai instansi pemerintah dalam hal ini Seksi Pencegahan dan perselisishan Hubungan Industrial Dinas Tenaga Kerja dan Transmigrasi Kabupaten Lampung Selatan yang bertanggung jawab di bidang ketenagakerjaan yang memenuhi syarat-syarat sebagai mediator yang ditetapkan oleh Menteri Tenaga Kerja.

\subsubsection{Pengadilan Hubungan Industrial}

Menurut pasal 56 UU No. 2 Tahun 2004, Pengadilan Hubungan Industrial mempunyai kompetensi absolut untuk memeriksa dan memutus :

a) Ditingkat pertama mengenai perselisihan hak.

b) Ditingkat pertama dan terakhir mengenai perselisihan kepentingan.

c) Ditingkat pertama mengenai perselisihan pemutusan hubungan kerja.

d) Ditingkat pertama dan terakhir mengenai perselisihan antar serikat pekerja/serikat buruhdalam satu perusahaan.

Upaya Pemerintah Untuk Mencegah dan Mengatasi Perselisihan Hubungan Indistrial. Penyelesaian perselisihan hubungan industrial adalah sala satu komponen dari sistem hukum ketenagakerjaan. Sebagai sub system dari system hukum ketenagakerjaan maka kwalifikasi tentang keberadaan penyelesaian perselisihan hubungan industrial sangat dipengaruhi oleh sub system-sub system hukum ketenagakerjaan lainnya.

\subsection{Analisis Kinerja}

\subsubsection{Efektivitas}


Efektivitas adalah suatu tingkat keberhasilan yang dihasilkan oleh seseorang atau organisasi dengan cara tertentu sesuai dengan tujuan yang hendak dicapai. Dengan kata lain, semakin banyak rencana yang berhasil dicapai maka suatu kegiatan dianggap semakin efektif. Maka disini penulis menjelaskan efeketifitas kinerja pada seksi pencegahan dan penyelesaian hubungan industrial.

Dalam penyelesaian perselisihan hubungan industrial selama tahun 2019 jumlah kasus 17 yang masuk dan telah diselesaikan sampai tahap akhir melalui mediasi. maka dapat disimpulkan penyelesaian perselisihan hubungan industrial cukup efektif. Berikut penjelasan dari Kasi Penyelesaian Hubungan Industrial Dinas Tenaga Kerja dan Transmigrasi Kabupaten Lampung Selatan, ketika di mintai keterangan oleh penulis.

\subsubsection{Efisiensi}

Efisiensi adalah ukuran keberhasilan suatu kegiatan yang dinilai berdasarkan jumlah biaya/sumber daya yang digunakan untuk mencapai hasil yang diinginkan. Dalam hal ini, semakin sedikit sumber daya yang digunakan untuk mencapai hasil yang diharapkan, prosesnya dapat dikatakan lebih efisien.

Kasi penyelesaian perselisihan hubungan industrial melakukan efisisensi dalam melakukan pencegahan dan penyelesaiaan perselisihaan hubungan industrial dengan membentuk lembaga kerja sama (LKS). bipatrit antara pihak pekerja dan pihak perusahaan.

\subsubsection{Kualitas}

Kualitas atau mutu adalah tingkat baik buruknya atau taraf atau derajat sesuatu. Istilah ini banyak digunakan dalam dalam bisnis, rekayasa, dan manufaktur dalam kaitannya dengan teknik dan konsep untuk memperbaiki kualitas produk atau jasa yang dihasilkan.

\subsubsection{Produktivitas}

Produktivitas merupakan nisbah atau rasio antara hasil kegiatan "ouput, keluaran" dan segala pengorbanan "biaya" untuk mewujudkan hasil tersebut "input, masukan". Produktivitas Dinas Tenaga kerja dan Transmigrasi Kabupaten Lampung Selatan dalam melaksanakan pencegahan dan penyelesaian perselisihan hubungan industrial cukup baik, hal ini dapat dilihat pada tabel data penyelesaian perselisihan hubungan industrial pada bulan maret tahun 2019 terdapat 4 kasus PHK kemudian yang telah dilakukan penyelesaian melalui perjanjian bersama (PB) berjumlah 3 kasus dan melalui anjuran sebanyak 1 kasus. Selain itu juga pada bulan mei terdapat 2 kasus PHK dan semuanya telah dilakukan penyelesaian dengan perjanjian bersama (PB) yakni berjumlah 2 kasus. Dari contoh kasus pada bulan maret dan mei, Dinas Tenaga kerja dan Transmigrasi telah berhasil menyelesaikan perselisihan hamper 100 persen. Berikut ini hasil wawancara penulis dengan Kabid Hubungan Industrial Dinas Tenaga Kerja dan Transmigrasi. 
Data Penyelesaian Perselisihan Hubungan Industrial Dinas Tenaga Kerja Dan Transmigras

Kabupaten Lampung Selatan Data

Tabel 3

\begin{tabular}{|c|c|c|c|}
\hline Tahun & $\begin{array}{c}\text { Jumlah } \\
\text { Kasus }\end{array}$ & Diselesaikan & $\begin{array}{c}\text { Tidak } \\
\text { Diselesaikan }\end{array}$ \\
\hline 2017 & 21 & 21 & - \\
\hline 2018 & 19 & 19 & - \\
\hline 2019 & 17 & 17 & - \\
\hline
\end{tabular}

Dalam tabel di atas dapat disimpulkan bahwa dalam 3 tahun terakhir Dinas Tenaga kerja dan Transmigrasi selalu menyelesaikan setiap kasus yang masuk setiap tahunnya.

\subsubsection{Kualitas Kehidupan Kerja}

Kualitas Kehidupan Kerja adalah pendekatan sistem manajemen atau cara pandang organisasi dengan tujuan untuk meningkatkan kualitas kehidupan karyawan dalam lingkungan kerjanya secara simultan dan berkesinambungan.

\subsubsection{Inovasi}

Inovasi (bahasa Inggris: innovation) dapat diartikan sebagai proses dan/atau hasil pengembangan pemanfaatan /mobilisasi pengetahuan, keterampilan (termasuk keterampilan teknologis) dan pengalaman untuk menciptakan atau memperbaiki produk (barang dan/atau jasa), proses, dan/atau sistem yang baru, yang memberikan nilai yang berarti atau secara signifikan (terutama ekonomi dan sosial).

Dalam pencegahan dan penyelesaian Hubungan industrial Dinas Tenaga Kerja dan Transmigrasi juga telah melakukan terobosan -terobosan atau inovasi dengan merumuskan pola kerja yang lebih sesuai dengan zaman. Berikut ini penjelasaan dari Kasi Penyelesaian Hubungan Industrial Dinas Tenaga kerja dan Transmigrasi Kabupaten Lampung Selatan.

\section{PENUTUP}

\subsection{Simpulan}

Pengukuran Kinerja Dinas Tenaga Kerja dan Transmigrasi Kabupaten Lampung Selatan dalam mencegah dan menyelesaikan perselisihan hubungan industrial adalah dengan melakukan analisis dengan menggunakan indikator kinerja yaitu, Efektifitas, efisiensi, kualitas, produktivitas, Kualitas kehidupan kerja, dan Inovasi. Dengan melakukan analisis Indikator Kinerja terhadap Kinerja Dinas Tenaga kerja dan Transmigrasi Kabupaten Lampung Selatan dalam Mencegah dan menyelesaikan perselisishan hubungan industrial tersebut. Pihak Dinas Tenaga Kerja dan Transmigrasi bagian Hubungan Industrial Seksi Penyelesaian Hubungan Industrial dapat menyusun rencana kerja dan program yang lebih baik dan terus meningkatkan pelayanan kepada masyarakat.

Pencegahan dan penyelesaian hubungan industrial oleh Dinas Tenaga kerja dan transmigrasi Kab. Lampung Selatan ini memiliki dampak terhadap stabilitas kerja baik pihak perusahaan dan pihak pekerja. Yang dapat dilihat selama tiga tahun terakhir 2017-2019 berhasil menyelesaian berbagai macam kasus perselisihan di lingkungan Kabupaten Lampung Selatan. 
Volume 1 Nomor 1

Dapat disimpulkan bahwa kinerja Pencegahan dan penyelesaian hubungan industrial Dinas Tenaga Kerja dan Transmigrasi telah membantu menyelesaian konflik para pekerja dengan perusahaan, sehingga membantu mewujudkan lingkungan kerja yang kondusif dan meningkatkan kesejahteraan masyarakat. Dan menurunkan tingkat pengangguran.

\subsection{Saran}

Saran yang dapat diberikan berdasarkan penelitian ini adalah sebagai berikut:

1. Dinas Tenaga kerja dan Transmigrasi Kabupaten Lampung Selatan Khususnya Bidang Hubungan Industrial seksi Pencegahan dan Penyelesaian Hubungan Industrial yang merupakan lembaga atau institusi yang melayani masyarakat khusunya menyelesaikan perselisishan hubungan industrial antara perusahaan dan pekerja atau serikat pekerja hendaknya terus melakukan inovasi dalam menyelesaikan perselisihan hubungan industrial sebagai salah satu upaya untuk membangun produktivitas dan kenyaman kerja di lingkungan Kabupaten lampung Selatan.

2. Dinas Tenaga Kerja dan Transmigrasi Kabupaten Lampung Selatan hendaknya terus mempertahankan pelayanan yang professional dan berkualitas kepada masyarakat.

\section{DAFTAR BUKU}

Arikunto,Suharsimi.2002. Prosedur Penelitian, Suatu Pendekatan Praktek. Jakarta: Rineka Cipta, Cetakan V

\section{A.W.Widjaja,2006.Administraasi} Kepegawaian. Rajawali,

Djohar, 2008,

Pengantar Pendidikan Transformatif.

Yogyakarta : Teras

Husaini Usman, 1996, Metodologi Penelitian Sosial,Jakarta: Bumi Aksara

Bernardin, H. John \& Joyce E. A. Russell. 1993. Human Resource Management. Singapore : McGraw Hill Inc

Bernardin and Russel. 1993. Human Resource Management,An. Experimential Approach, terjemahan. Jakarta: Pustaka Binaman Presindo.

Dharma, Agus . 1991. Manajemen Prestasi Kerja. Jakarta: Rajawali Pers.

Dharma, Surya, 2011. Manajemen Kinerja (Falsafah Teori dan Penerapannya), cetakan keempat. Yogyakarta: Pustaka Pelajar.

Fahmi. Irham. 2007. Manajemen Kinerja Teori dan Aplikasi. Bandung: Alfabeta.

Handoko, T. Hani. 1995. Manajemen. Edisi 2. Yogyakarta: BPFE.

Hasibuan, Malayu S.P. 2003.Manajemen Sumber Daya Manusia.Jakarta: Bumi Aksara.

Kartini Kartono. 2003. Pemimpin Dan Kepemimpinan. Jakarta : PT. Raja Grafindo Persada 
Lexy J. Moleong.2002.Metodologi Penelitian Kualitatif. Bandung: Remaja Rosdakarya.

Lembaga Administrasi Negara Republik Indonesia. 1996. Sistem Administrasi Negara Republik Indonesia. Jilid II/Edisi Ketiga. Jakarta: Toko Gunung Agung.

Mahmudi, 2005, Manajemen Kinerja Sektor Publik, Jakarta: STIM YKPN

Mangkunegara. A.A Anwar Prabu. 2005.Evaluasi Kinerja Sumber Daya Manusia. Bandung: Refika Aditama.

Moeheriono. 2011. Indikator Kinerja Utama. Jakarta: Rajawali Pers.

Mujiono. 2002. Kepemimpinan dan Keorganisasian : Yogyakarta UIII Press

Mowday, R.T, Porter, L.W dan Steers R.M. (1982). Employee Organization Lingkages: The Psychology of Commitment, Absenteeism and Turnover. London: Academic Press Inc

Musanef. $1984 \quad$. Manajemen Kepegawaian di Indonesia. Jakarta : Gunung Agung.

Pasolong,Harbani. $2012 . \quad$ Metode Penelitian Administrasi Publik. Bandung : Alfabeta.

Peraturan Bupati (Perbup) Kabupaten Lampung Selatan Nomor 9 Tahun 2016. tentang Rincian Tugas Jabatan, Fungsi Dan Tata Kerja Dinas Tenaga Kerja Dan Transmigrasi Kabupaten Lampung Selatan.

Prawirosentono, Suryadi.1999. Kebijakan Kinerja Karyawan. Yogyakarta: BPFE
Rivai, Veithzal . 2004. Manajemen Sumber Daya Manusia untuk Perusahaan. Jakarta: PT.Raja Grafindo Persada. Sadili Samsudin. 2005. Manajemen Sumber Daya.Manusia. Bandung Pustaka Setia.

Sedarmayanti .2007. Manajemen Sumber Daya Manusia. Bandung: Refika Aditama.

Simanjuntak,Payaman. 2005.,Manajemen dan Evaluasi Kinerja, cetakan pertama. Jakarta: Bumi Aksara.

Undang-undang Nomor 2 Tahun 2004 tentang Penyelesaian Perselisihan Hubungan Industrial. 